\title{
GMR
}

\section{Karyotype asymmetry in Cynodon Rich. (Poaceae) accessions}

\author{
R.B. Chiavegatto ${ }^{1}$, C.M.P. Paula ${ }^{1}$, F. Souza Sobrinho ${ }^{2}$, F.R.G. Benites ${ }^{2}$ \\ and V.H. Techio ${ }^{1}$ \\ ${ }^{1}$ Laboratório de Citogenética Vegetal, Departamento de Biologia, \\ Universidade Federal de Lavras, Lavras, MG, Brasil \\ ${ }^{2}$ Empresa Brasileira de Pesquisa Agropecuária, Embrapa Gado de Leite, \\ Juiz de Fora, MG, Brasil \\ Corresponding author: V.H. Techio \\ E-mail: vhtechio@dbi.ufla.br \\ Genet. Mol. Res. 15 (4): gmr15049152 \\ Received September 2, 2016 \\ Accepted October 19, 2016 \\ Published December 2, 2016 \\ DOI http://dx.doi.org/10.4238/gmr15049152
}

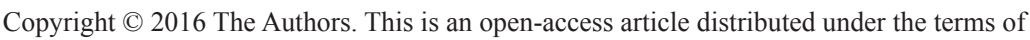
the Creative Commons Attribution ShareAlike (CC BY-SA) 4.0 License.

\begin{abstract}
Cynodon is a genus of plants with forage potential that has attracted the interest of breeders. These species have high morphological variability in a large number of varieties and cytotypes, hampering identification. This study aimed to determine the karyotype asymmetry index among accessions of Cynodon to discriminate between them. Karyotype symmetry was based on three estimates, which were compared. The basic number for the genus is $x=9$. The results of the chromosome count and DNA quantification, respectively, were as follows: two diploid accessions $(2 \mathrm{n}=2 \mathrm{x}=18$ and $1.08 \pm 0.094$ to 1.17 $\pm 0.036 \mathrm{pg}$ DNA and \pm standard deviation), one triploid accession ( $2 \mathrm{n}$ $=3 \mathrm{x}=27$ and $1.63 \pm 0.017 \mathrm{pg}$ DNA), four tetraploid accessions $(2 \mathrm{n}=$ $4 \mathrm{x}=36$ and $1.88 \pm 0.069$ to $2.10 \pm 0.07 \mathrm{pg}$ DNA), and one pentaploid accession $(2 \mathrm{n}=5 \mathrm{x}=45$ and $2.55 \pm 0.098 \mathrm{pg}$ DNA). C. incompletus var. hirsutus had the longest total length of the haploid lot $(29.05 \mu \mathrm{m})$, with
\end{abstract}

Genetics and Molecular Research 15 (4): gmr15049152 
chromosomes that ranged from 1.7 to $6.2 \mu \mathrm{m}$ in length. On the basis of the karyotype asymmetry indices, the accessions were divided into two groups: 1) C. dactylon var. dactylon, C. transvaalensis, C. dactylon var. polevansii, three accessions of Cynodon sp, and C. nlemfuensis; and 2) C. incompletus var. hirsutus. This is the first description of tetraploidy in C. transvaalensis. The karyotypic data facilitated a determination of the degree of proximity between the accessions.

Key words: Chromosome symmetry; Cynodon; DNA content; Polyploidy

\section{INTRODUCTION}

Cynodon Rich. (Poaceae) is a genus of perennial plants that is typical of tropical and subtropical regions and is widely adapted to various environments. It has high morphological variability and has multiple applications in various regions worldwide, such as its use in pasture and stored forage, soil cover and sward, on golf courses, and in gardens (Wu, 2011; Jewell et al., 2013).

Species of this group, particularly Cynodon dactylon (L.) Pers., have attracted the interest of breeders because of their ease of cultivation, high forage production, high nutritional value (Pedreira, 1996), high growth rate, grazing resistance, high carrying capacity, and rapid establishment (de Lima and Vilela, 2005). The main objective of forage breeding programs is to obtain genotypes with desirable agronomic traits, such as high forage production, persistence, tolerance to poorly drained soils and frosts, and forage quality for livestock systems, including, beef and milk cattle, horse feeding, and hay and silage production (Vilela, 2005).

Species of Cynodon have been separated into two groups based on their morphology (Nascimento et al., 2002). "Bermuda grasses", represented by C. dactylon, have rhizomes and stolons, and "star grasses" [C. plectostachyus (K. Schum.) Pilg., C. aethiopicus Clayton \& J.R. Harlan, and C. nlemfuensis Vanderryst] have only stolons. However, there are varieties and cytotypes with morphological similarities; consequently, many mistakes in classification occur (Caro and Sánchez, 1969; Harlan et al., 1970a; Clayton et al., 2006). In addition to the divergences in taxonomy, there is also controversy regarding the number of species and varieties of the genus, the records of which range from 9 to 14 species (Caro and Sánchez, 1969; Harlan et al., 1970a; Clayton et al., 2006). Thirteen species of Cynodon are recorded in the Plant List (http://www.theplantlist.org/), and for C. dactylon, one subspecies and 23 varieties are described. These ambiguities are a problem for conservation and the exchange of genetic resources, because many plants can be incorporated into botanical and germplasm collections or even incorrectly used in crosses.

Cytogenetic information, such as karyotype characterization and nuclear DNA quantification, is important in the discrimination of species, varieties, and cytotypes, and for germplasm handling, and has been successfully used in grasses including Pennisetum (Techio et al., 2002, 2010), Paspalum (Vaio et al., 2005), Setaria (Nani et al., 2015), and Brachiaria (Nani et al., 2016). However, cytogenetic studies have not been conducted on Cynodon. The existing information is limited to chromosome counts and the determination of ploidy level, without considering taxonomic differences. The genus has the basic chromosome number $\mathrm{x}$ $=9$ (Dhaliwal and Gupta, 2011; Zhi-Yun et al., 2013), but plants with different ploidy levels

Genetics and Molecular Research 15 (4): gmr15049152 
have been described, including diploid $(2 \mathrm{n}=2 \mathrm{x}=18)$, triploid $(2 \mathrm{n}=3 \mathrm{x}=27)$, tetraploid $(2 \mathrm{n}$ $=4 \mathrm{x}=36)$, and, in smaller numbers, pentaploid $(2 \mathrm{n}=5 \mathrm{x}=45)$ and hexaploid $(2 \mathrm{n}=6 \mathrm{x}=$ 54) (Harlan et al., 1970a; Wu and Taliaferro, 2009). The goal of this study was to determine karyotype asymmetry among Cynodon accessions, in order to discriminate between them and establish their genetic relationships.

\section{MATERIAL AND METHODS}

\section{Plant material}

We evaluated seven Cynodon accessions (Table 1) that were donated by Embrapa Gado de Leite, Juiz de Fora, Minas Gerais State, Brazil. The accessions were obtained from the Active Germplasm Bank, United States Department of Agriculture, Tifton, GA, USA.

Table 1. Identification of accessions/species of the genus Cynodon.

\begin{tabular}{l|l}
\hline Accession & Identification* \\
\hline PI 291151-20 & Cynodon dactylon var. dactylon (L.) Pers. \\
\hline PI289923-09 & Cynodon transvaalensis Burtt-Davy \\
\hline PI 289750-10 & Cynodon dactylon var. polevansii (Stent) J.R. Harlan \& de Wet \\
\hline PI 29175301 PL 15 & Cynodon incompletus var. hirsutus (Stent) de Wet \& J.R. Harlan \\
\hline PI 291755-24 & Cynodon sp \\
\hline PI 224148-28 & Cynodon sp \\
\hline PI 224147-13 & Cynodon sp \\
\hline ERX 7** & Cynodon nlemfuensis Vanderryst \\
\hline
\end{tabular}

*Standardization of synonyms followed that of the United States Department of Agriculture (https://npgsweb.arsgrin.gov/gringlobal/site.aspx?id=22). ${ }^{* *}$ Cynodon nlemfuensis (purple star grass) accession developed by Embrapa Gado de Leite breeding program.

\section{Cytogenetic analysis}

For cytogenetic evaluations, root tips were pre-treated with cycloheximide $(0.025 \%)$ at room temperature for $2 \mathrm{~h}$. The roots were then fixed in Carnoy's solution (three parts of absolute ethyl alcohol to one part acetic acid) and stored at $-20^{\circ} \mathrm{C}$ until slide preparation. The roots were subjected to enzymatic digestion with an enzyme mix containing Onozuka R10 cellulase $(0.7 \%)$, cellulase $(0.7 \%)$, pectolyase $(1 \%)$, and cytohelicase (1\%) (SigmaAldrich) at $37^{\circ} \mathrm{C}$ for $60 \mathrm{~min}$. Slides were prepared by the flame-drying technique (Dong et al., 2000), and stained with 5\% Giemsa. Photomicrographs of the metaphases were taken with a microscope (Axio Lab. A1, Zeiss) with an image-capture camera (AxioCam ICc1), and analyzed using the AxioVision 4.8.2 software.

\section{Chromosome measurements and karyotype analysis}

Morphometric characteristics of the chromosomes [mean lengths of the short arm (c) and the long arm (1)] were obtained using the software MicroMeasure 3.3 (Reeves and Tear, 2000). We then calculated the total length of the chromosome, the total length of the haploid

Genetics and Molecular Research 15 (4): gmr15049152 
lot (TLHL), and the relative length of each chromosome. The morphological classification of the chromosomes was based on the ratio of arms proposed by Levan et al. (1964). This information was used for assembling karyograms of the Cynodon accessions with Adobe Photoshop. Ten metaphases were measured per accession.

TLHL values were tested by analysis of variance (ANOVA) and the Tukey test at the 5\% probability level using the software Sisvar (Ferreira, 2011), in order to compare the accessions.

To determine karyotype symmetry, we employed the criteria of Stebbins (1971), Zarco (1986), and Peruzzi and Eroğlu (2013). Stebbins (1971) considers the ratio of the arms and the lengths of the chromosomes to assess karyotype symmetry. The criteria of Zarco (1986) are based on the indices A1, intrachromosomal asymmetry (relative to the centromere position), and A2, interchromosomal asymmetry (relative to size). Peruzzi and Eroğlu (2013) propose the use of $\mathrm{M}_{\mathrm{CA}}$ parameters (mean centromeric asymmetry) for intrachromosomal asymmetry and $\mathrm{CV}_{\mathrm{CL}}$ (coefficient of variation of chromosome length) for interchromosomal asymmetry.

\section{DNA quantification}

To estimate the DNA content, three samples of each accession evaluated (Table 1) were quantified. Young Cynodon leaf tissue $(20-30 \mathrm{mg})$ was macerated with the same amount of material from Pisum sativum (internal reference standard, 2C DNA content $=9.09 \mathrm{pg}$ ) on a Petri dish containing $1 \mathrm{~mL}$ cold buffer (Marie and Brown, 1993) to obtain a nuclear suspension (Dolezel, 1997). To this nuclear suspension, we added $25 \mu \mathrm{L}$ propidium iodide, and for each sample we quantitated at least 10,000 nuclei.

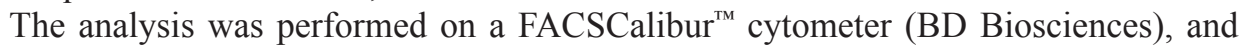
histograms were obtained using the CellQuest ${ }^{\mathrm{TM}}$ software and analyzed in WinMDI 2.9. The nuclear DNA content of the plants was estimated by comparison with the G1 peak position of the internal reference standard. DNA content values were compared by ANOVA and the Tukey test using Sisvar.

\section{RESULTS}

Data on the chromosome number and ploidy level of all eight Cynodon accessions evaluated (Figures 1 and 2 and Table 2) were corroborated by the estimated nuclear DNA content. Whereas the basic number of chromosomes proposed for the genus is $\mathrm{x}=9$, the species C. nlemfuensis (ERX 7) and C. incompletus var. hirsutus (PI 29175301 PL 15) were diploid $(2 \mathrm{n}=2 \mathrm{x}=18)$, with the smallest amount of nuclear DNA $(1.08 \pm 0.094$ and $1.17 \pm$ $0.036 \mathrm{pg}$, respectively) (Figure 1A and B). Cynodon sp (PI 291755-24) was triploid with $2 \mathrm{n}=3 \mathrm{x}=27$ and $1.63 \pm 0.017 \mathrm{pg}$ of DNA (Figure 1C). The accessions $C$. dactylon var. dactylon (PI 291151-20), C. transvaalensis (PI 289923-09), and Cynodon sp (accessions PI 224148-28 and PI 224147-13) were tetraploid ( $2 \mathrm{n}=4 \mathrm{x}=36$, Figure $1 \mathrm{D}-\mathrm{G})$, with the nuclear DNA content varying between $1.88 \pm 0.069$ and $2.10 \pm 0.07 \mathrm{pg}$. In terms of DNA content, there were no significant differences between these four accessions/species, but they were statistically different to the other species. C. dactylon var. polevansii (PI 289750-10) had the highest nuclear DNA content $(2.55 \pm 0.098 \mathrm{pg})$, which was compatible with its higher ploidy level $(2 \mathrm{n}=5 \mathrm{x}=45$ chromosomes) (Figure $1 \mathrm{H})$.

Genetics and Molecular Research 15 (4): gmr15049152 


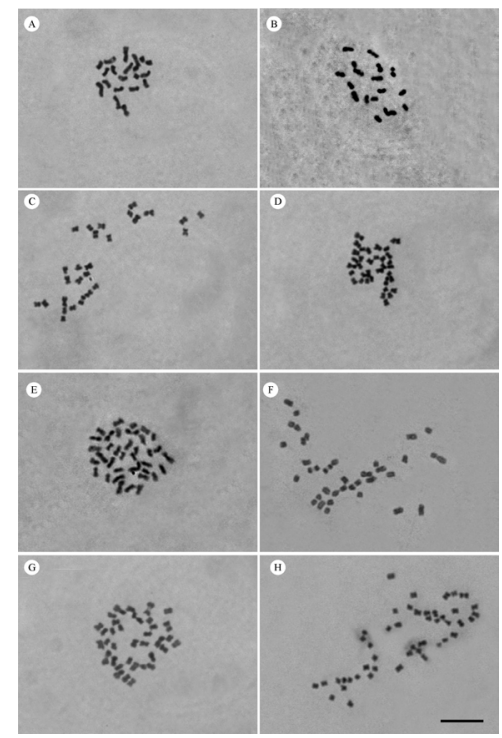

Figure 1. Mitotic metaphases of Cynodon accessions. A. C. incompletus var. hirsutus (PI 29175301 PL 15; 2n $=2 \mathrm{x}$ $=18) ;$ B. C. nlemfuensis (ERX 7; $2 \mathrm{n}=2 \mathrm{x}=18)$; C. Cynodon sp (PI 291755-24; $2 \mathrm{n}=3 \mathrm{x}=27)$; D. C. dactylon var. dactylon (EGL1; $2 \mathrm{n}=4 \mathrm{x}=36) ;$ E. C. transvaalensis (PI 289923-09; $2 \mathrm{n}=4 \mathrm{x}=36$ ); F. Cynodon $\mathrm{sp}$ (PI 224148-28; $2 \mathrm{n}=4 \mathrm{x}=36)$; G. Cynodon sp (PI 224147-13; $\mathrm{n}=4 \mathrm{x}=36)$; H. C. dactylon var. polevansii (PI 289750-10; $2 \mathrm{n}=$ $5 \mathrm{x}=45)$. Bar $=10 \mu \mathrm{m}$.

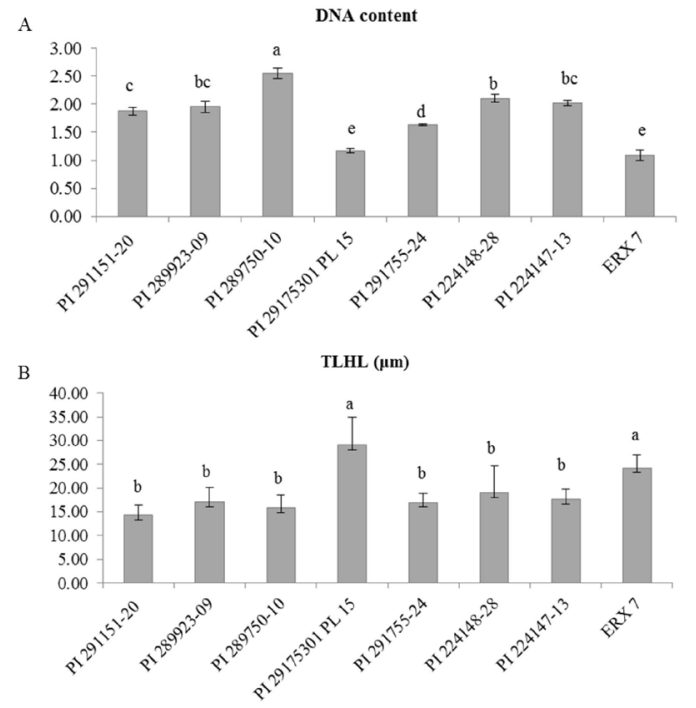

Figure 2. Nuclear DNA content (pg) and \pm standard deviation (A) and total length of the haploid lot (TLHL) (mm) (B) of Cynodon. C. incompletus var. hirsutus (PI 29175301 PL 15; 2n = 2x = 18); C. nlemfuensis (ERX 7; $2 \mathrm{n}=$ 2x = 18); Cynodon sp (PI 291755-24; 2n =3x =27); C. dactylon var. dactylon (PI 291151-20; $2 \mathrm{n}=4 \mathrm{x}=36$ ); $C$. transvaalensis (PI 289923-09; $2 \mathrm{n}=4 \mathrm{x}=36$ ); Cynodon $\mathrm{sp}$ (PI 224148-28; $2 \mathrm{n}=4 \mathrm{x}=36$ ); Cynodon $\mathrm{sp}$ (PI 224147$13 ; 2 \mathrm{n}=4 \mathrm{x}=36$ ); C. dactylon var. polevansii (PI 289750-10; $2 \mathrm{n}=5 \mathrm{x}=45$ ). Means followed by different letters were significantly different by the Tukey test at the $5 \%$ probability level.

Genetics and Molecular Research 15 (4): gmr15049152 
Table 2. Cynodon accession chromosome numbers.

\begin{tabular}{l|l|c}
\hline Accession & Species & Chromosome number \\
\hline PI 291151-20 & Cynodon dactylon var. dactylon & $2 \mathrm{n}=4 \mathrm{x}=36$ \\
\hline PI 289923-09 & Cynodon transvaalensis & $2 \mathrm{n}=4 \mathrm{x}=36$ \\
\hline PI 289750-10 & Cynodon dactylon var. polevansii & $2 \mathrm{n}=5 \mathrm{x}=45$ \\
\hline PI 29175301 PL 15 & Cynodon incompletus var. hirsutus & $2 \mathrm{n}=2 \mathrm{x}=18$ \\
\hline PI 291755-24 & Cynodon $\mathrm{sp}$ & $2 \mathrm{n}=3 \mathrm{x}=27$ \\
\hline PI 224148-28 & Cynodon $\mathrm{sp}$ & $2 \mathrm{n}=4 \mathrm{x}=36$ \\
\hline PI 224147-13 & Cynodon sp & $2 \mathrm{n}=4 \mathrm{x}=36$ \\
\hline ERX 7 & Cynodon nlemfuensis & $2 \mathrm{n}=2 \mathrm{x}=18$ \\
\hline
\end{tabular}

With the exception of the diploid accession C. incompletus var. hirsutus (PI 29175301 PL 15) that had only submetacentric chromosomes (sm) with a 9sm karyotype formula, the karyotypes of the other accessions were composed of only metacentric chromosomes $(\mathrm{m})$ (Figure 3 and Table 3). C. nlemfuensis (ERX 7) and C. incompletus var. hirsutus (PI 29175301 PL 15), despite having a lower amount of DNA, had the greatest total lengths of the haploid lot (24.21 and $29.05 \mathrm{~mm}$, respectively), and significantly differed from the other accessions (Figure 2). In C. nlemfuensis (ERX 7) and C. incompletus var. hirsutus (PI 29175301 PL 15) accession, the lengths of the largest and smallest chromosome pairs corresponded to 15.88 and $7.92 \%$, respectively, of the TLHL. Among the polyploid accessions, PI 224147-13 (Cynodon sp) had the largest and smallest chromosome pairs, which corresponded to 17.18 and $7.44 \%$, respectively, of the TLHL (Table 4).

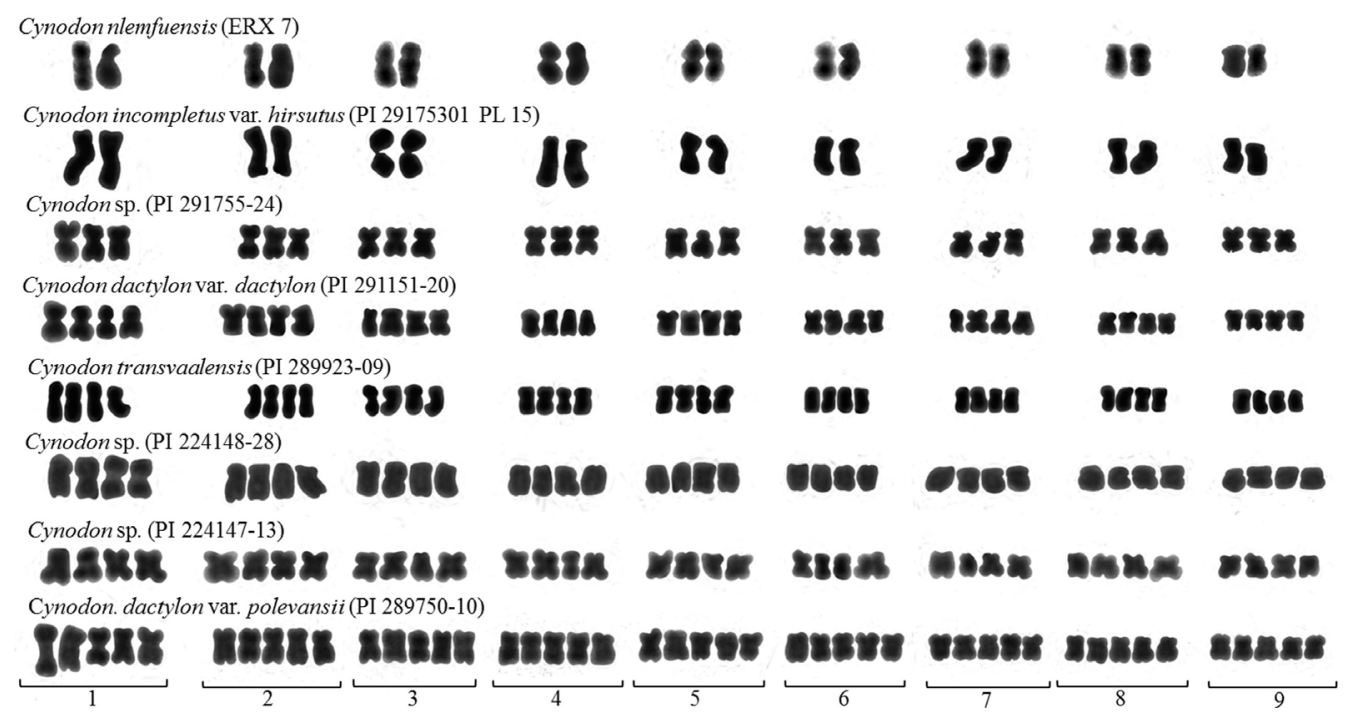

Figure 3. Karyotypes of Cynodon accessions. A. C. nlemfuensis $(2 \mathrm{n}=2 \mathrm{x}=18)$; B. C. incompletus var. hirsutus (PI 29175301 PL 15; 2n =2x = 18); C. Cynodon sp (PI 291755-24; $2 \mathrm{n}=3 \mathrm{x}=27)$; D. C. dactylon var. dactylon (PI 291151-20; $2 \mathrm{n}=4 \mathrm{x}=36$ ); E. C. transvaalensis (PI 289923-09; $2 \mathrm{n}=4 \mathrm{x}=36$ ); F. Cynodon sp (PI 224148-28; $2 \mathrm{n}=$ $4 \mathrm{x}=36) ;$ G. Cynodon sp (PI 224147-13; $2 \mathrm{n}=4 \mathrm{x}=36) ;$ H. C. dactylon var. polevansii (PI 289750-10; $2 \mathrm{n}=5 \mathrm{x}=$ 45). $\mathrm{Bar}=10 \mu \mathrm{m}$.

Genetics and Molecular Research 15 (4): gmr15049152 
Table 3. Arm ratio and karyotypic formulae of Cynodon accessions.

\begin{tabular}{l|c|c|c|c|c|c|c|c}
\hline & \multicolumn{7}{|c|}{ Accessions and arm ratio } & \\
\cline { 2 - 9 } & PI 291151-20 & PI 289923-09 & PI 289750-10 & PI 29175301 PL 15 & PI 291755-24 & PI 224148-28 & PI 224147-13 & ERX 7 \\
\hline Chromosome & & & & & & & & \\
\hline 1 & 1.489 & 1.57 & 1.393 & 2.069 & 1.638 & 1.643 & 1.39 & 1.57 \\
\hline 2 & 1.524 & 1.56 & 1.551 & 2.618 & 1.565 & 1.619 & 1.388 & 1.5 \\
\hline 3 & 1.552 & 1.474 & 1.436 & 2.238 & 1.593 & 1.597 & 1.391 & 1.34 \\
\hline 4 & 1.498 & 1.52 & 1.35 & 2.097 & 1.542 & 1.518 & 1.387 & 1.26 \\
\hline 5 & 1.421 & 1.54 & 1.451 & 2.365 & 1.496 & 1.557 & 1.35 & 1.27 \\
\hline 6 & 1.412 & 1.511 & 1.368 & 1.998 & 1.533 & 1.574 & 1.445 & 1.24 \\
\hline 7 & 1.412 & 1.388 & 1.372 & 1.864 & 1.355 & 1.448 & 1.427 & 1.22 \\
\hline 8 & 1.363 & 1.55 & 1.4 & 2.211 & 1.383 & 1.548 & 1.367 & 1.2 \\
\hline 9 & 1.38 & 1.395 & 1.343 & 1.798 & 1.509 & 1.395 & 1.349 & 1.2 \\
\hline Karyotype formula & $9 \mathrm{~m}$ & $9 \mathrm{~m}$ & $9 \mathrm{~m}$ & $9 \mathrm{sm}$ & $9 \mathrm{~m}$ & $9 \mathrm{~m}$ & $9 \mathrm{~m}$ & $9 \mathrm{~m}$ \\
\hline
\end{tabular}

PI 291151-20, C. dactylon var. dactylon; PI 289923-09, C. transvaalensis; PI 289750-10, C. dactylon var. polevansii; PI 29175301 PL 15, C. incompletus var. hirsutus; PI 291755-24, PI 224148-28, and PI 224147-13, Cynodon sp; ERX 7, C. nlemfuensis; m, metacentric; sm, submetacentric.

Table 4. Mean relative length (\%) and karyotype symmetry estimates of chromosomes of Cynodon accessions according to the criteria of Stebbins (1971), Zarco (1986), and Peruzzi and Eroğlu (2013).

\begin{tabular}{l|c|c|c|c|c|c|c|c}
\hline & \multicolumn{7}{|c}{ Accession and mean relative length (\%) } & \\
\cline { 2 - 9 } & PI 291151-20 & PI 289923-09 & PI 289750-10 & PI 29175301 PL 15 & PI 291755-24 & PI 224148-28 & PI 224147-13 & ERX 7 \\
\hline Chromosome & & & & & & & & \\
\hline 1 & 16.03 & 16.396 & 15.535 & 15.887 & 15.669 & 16.592 & 17.181 & 15.567 \\
\hline 2 & 13.708 & 13.814 & 13.071 & 13.425 & 13.347 & 14.076 & 13.827 & 13.757 \\
\hline 3 & 12.262 & 12.483 & 12.146 & 12.18 & 12.144 & 12.767 & 12.195 & 12.759 \\
\hline 4 & 11.385 & 11.497 & 11.386 & 11.718 & 11.492 & 11.531 & 11.197 & 11.332 \\
\hline 5 & 10.696 & 10.587 & 10.723 & 10.868 & 10.672 & 10.711 & 10.549 & 10.468 \\
\hline 6 & 10.033 & 9.907 & 10.213 & 10.025 & 10.079 & 9.902 & 9.995 & 10.055 \\
\hline 7 & 9.424 & 9.23 & 9.682 & 9.248 & 9.505 & 9.077 & 9.158 & 9.371 \\
\hline 8 & 8.716 & 8.565 & 9.091 & 8.725 & 8.955 & 8.237 & 8.448 & 8.754 \\
\hline 9 & 7.742 & 7.517 & 8.148 & 7.92 & 8.134 & 7.104 & 7.444 & 7.934 \\
\hline Stebbins & $4 \mathrm{~b}$ & $4 \mathrm{~b}$ & $4 \mathrm{a}$ & $2 \mathrm{~b}$ & $4 \mathrm{a}$ & $4 \mathrm{~b}$ & $4 \mathrm{~b}$ & $4 \mathrm{a}$ \\
\hline A1 & 0.309 & 0.332 & 0.288 & 0.528 & 0.336 & 0.351 & 0.279 & 0.527 \\
\hline A2 & 0.232 & 0.2504 & 0.202 & 0.225 & 0.211 & 0.269 & 0.268 & 0.225 \\
\hline MCA & 18.336 & 19.988 & 16.879 & 36.046 & 20.319 & 21.342 & 16.258 & 35.953 \\
\hline CV & 23.297 & 25.040 & 20.229 & 22.557 & 21.187 & 26.968 & 26.871 & 22.576 \\
\hline PI & $C$ & & & & & & & \\
\hline
\end{tabular}

PI 291151-20, C. dactylon var. dactylon; PI 289923-09, C. transvaalensis; PI 289750-10, C. dactylon var. polevansii; PI 29175301 PL 15, C. incompletus var. hirsutus; PI 291755-24, PI 224148-28, and PI 224147-13, Cynodon sp; ERX 7, C. nlemfuensis; A1, intrachromosomal asymmetry; A2, interchromosomal asymmetry; $\mathrm{M}_{\mathrm{CA}}$, mean centromeric asymmetry; $\mathrm{CV}_{\mathrm{CL}}$, coefficient of variation of chromosome length.

Based on the symmetry criteria proposed by Stebbins (1971), the karyotypes were divided into three categories: 4a for C. dactylon var. polevansii (PI 289750-10), Cynodon sp (PI 291755-24), and C. nlemfuensis (ERX 7); 4b for C. dactylon var. dactylon (PI 291151-20), C. transvaalensis (PI 289923-09), and Cynodon sp (PI 224148-28 and PI 224147-13); and $2 \mathrm{~b}$ for C. incompletus var. hirsutus (PI 29175301 PL 15) (Table 4). The estimated values of asymmetry obtained according to Zarco (1986) and Peruzzi and Eroğlu (2013) were identical and formed two groups. C. incompletus var. hirsutus (PI 29175301 PL 15) had the most asymmetric karyotype $\left(\mathrm{A} 1=0.528, \mathrm{~A} 2=0.225, \mathrm{M}_{\mathrm{CA}}=36.046\right.$, and $\left.\mathrm{CV}_{\mathrm{CL}}=22.557\right)$, while $C$. nlemfuensis (ERX 7) had the most symmetric $\left(\mathrm{A} 1=0.237, \mathrm{~A} 2=0.224, \mathrm{M}_{\mathrm{CA}}=22.355\right.$, and $\left.\mathrm{CV}_{\mathrm{CL}}=22.462\right)($ Table 4 and Figure $4 \mathrm{~A}$ and $4 \mathrm{~B})$. 

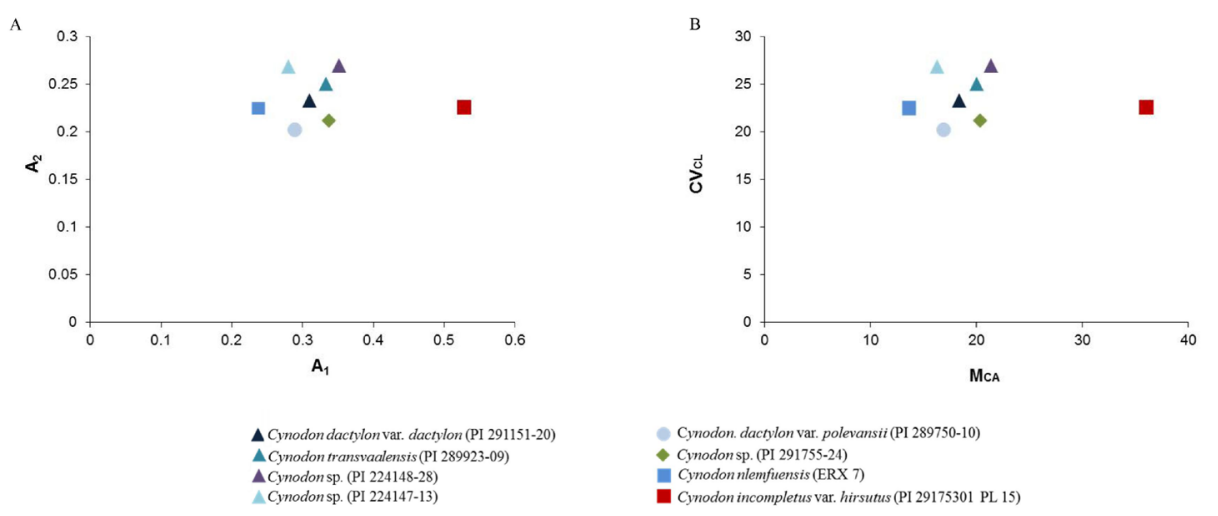

Figure 4. Karyotype asymmetry in Cynodon accessions. A. Indices of intrachromosomal asymmetry $\left(\mathrm{A}_{1}\right)$ and interchromosomal asymmetry $\left(\mathrm{A}_{2}\right)$ as proposed by Zarco (1986). B. Mean centromeric asymmetry (intrachromosomal asymmetry) $\left(\mathrm{M}_{\mathrm{CA}}\right)$ and coefficient of variation of the chromosomal length (interchromosomal asymmetry) $\left(\mathrm{CV}_{\mathrm{CL}}\right)$ according to Peruzzi and Eroğlu (2013).

\section{DISCUSSION}

The predominant level of ploidy for the accessions was tetraploid, although diploid, triploid, and pentaploid accessions were also observed and validated by DNA quantification. Silva and Snaydon (1995) evaluated 480 plants from 32 populations of $C$. dactylon collected from Sri Lanka; most were $2 \mathrm{n}=4 \mathrm{x}=36$, and about $20 \%$ were $2 \mathrm{n}=$ $2 \mathrm{x}=18$. The variation in ploidy levels (from diploid to hexaploid) in Cynodon has been described by several authors (Forbes and Burton, 1963; Harlan et al., 1970a; Dhaliwal and Gupta, 2011). This indicates that there is wide genetic variability in the group that is expressed as morphological, phenotypic, and biochemical variability, which are important characteristics for the origin and evolution of species (Schifino-Wittmann, 2004) and the development of improved cultivars (Wu and Taliaferro, 2009).

The chromosome counts of $C$. dactylon var. dactylon (PI 291151-20), C. incompletus var. hirsutus (PI 29175301 PL 15), and C. nlemfuensis (ERX 7) agreed with the observations made by Harlan et al. (1970b) in genotypes from Africa and Asia. The chromosome numbers of C. transvaalensis (PI 289923-09) and C. dactylon var. polevansii (PI 289750-10) $(2 \mathrm{n}=4 \mathrm{x}=$ 36 and $2 n=5 x=45$, respectively) differed from those reported by Harlan et al. (1970a), who cited $2 \mathrm{n}=2 \mathrm{x}=18$ and $2 \mathrm{n}=4 \mathrm{x}=36$, respectively, for these species.

This is the first record of tetraploidy in C. transvaalensis (accession PI 289923-09). This species is known as diploid $(2 \mathrm{n}=2 \mathrm{x}=18)$, is endemic to South Africa, and is recognized as a species by its distinctive morphology (de Wet and Harlan, 1970), which includes a small size, erect posture, thin, linear, and green leaves, and yellow inflorescences with two to four racemes in a single spiral (de Wet and Harlan, 1971). The occurrence of tetraploid plants, such as the C. transvaalensis accession PI 289923-09, suggests the occurrence of chromosomal duplication or the production of unreduced gametes in diploid species, which may be elucidated through meiotic analysis. This is important information for interspecific hybridization purposes, because $C$. transvaalensis (diploid) is used in crosses with $C$. dactylon var. dactylon (tetraploid) to produce hybrid cultivars that are triploid and infertile (Wu and Taliaferro, 2009). The existence of a tetraploid C. transvaalensis opens up new possibilities 
for combinations with the tetraploid $C$. dactylon for the possible generation of fertile hybrids, depending on the genomic/chromosomal affinity between them.

The triploidy $(2 \mathrm{n}=3 \mathrm{x}=27)$ that was observed in the accession PI 291755-24 (Cynodon sp) indicates that they are hybrid plants. Previous studies have reported triploid intra- and interspecific hybrids, natural and induced, in Cynodon (Forbes and Burton, 1963; de Wet and Harlan, 1970; Gupta and Srivastava, 1970). According to Gupta and Srivastava (1970), there are two theories for the origin of triploid cytotypes: 1) natural crosses between diploid and tetraploid individuals; and 2) natural crosses between diploid individuals with an unreduced gamete and a reduced gamete. de Wet and Harlan (1970) described C. x magennisii Hurcombe as a natural triploid that originated from a cross between $C$. dactylon (tetraploid) and C. transvaalensis (diploid), and proposed that C. $x$ magennisii Hurcombe would be an allopolyploid. An induced triploid was first described by Forbes and Burton (1963), who conducted a cross between diploid and tetraploid $C$. dactylon to originate a triploid hybrid. They detected a high frequency of trivalents in the hybrids, indicating homology between the genomes of tetraploid and diploid species. Harlan et al. (1970b) observed that artificial triploid hybrids from a cross between $C$. incompletus (diploid) and $C$. dactylon (tetraploid) formed nine bivalents and nine univalents. They concluded that there was no homology between the genomes of these species, and hybrids from this cross were infertile.

The origin of C. dactylon var. dactylon (tetraploid), such as accession PI 29115120 , has been associated with the union of the unreduced gametes of the ancestor $C$. dactylon var. aridus (Harlan et al., 1969). C. dactylon var. polevansii is described as strictly tetraploid $(2 \mathrm{n}=4 \mathrm{x}=36)$, and is found only near Barberspan in South Africa (Harlan et al., 1970b). However, plants of this species evaluated in the present study (PI 289750-10) had 2n $=5 \mathrm{x}=$ 45 chromosomes. In a previous classification, $C$. dactylon var. polevansii was classified as a species (C. polevansii) by Stent in 1927. In a study by Anderson et al. (2009), C. polevansii plants were identified as triploid, tetraploid, and pentaploid; the tetraploid and pentaploid plants were from Barberspan and the triploid plants were from Delareyville, South Africa. Pentaploids, such as accession IP 289750-10, can occur through crosses between hexaploid and tetraploid cytotypes (Wu, 2011).

Regarding DNA quantification, the mean coefficient of variation obtained by flow cytometry was approximately $0.58 \%$, which demonstrates the quality of the results and the reliability of the DNA content estimates, because values below $2 \%$ are considered high quality (Marie and Brown, 1993). The nuclear DNA contents obtained for the accessions analyzed in this study were similar to the values reported by Wu et al. (2006), Kang et al. (2008), and Gulsen et al. (2009). The variation in DNA found between the tetraploid accessions $C$. dactylon var. dactylon (PI 291151-20) and Cynodon sp (PI 224148-28) is common, as there are differences in DNA content between genotypes, populations, lineages, and cultivars within a species (Dolezel, 1997). This variation in the amount of DNA can be explained by variations in genome size between species within the same genus, or even within the same species.

Diploid accessions of C. nlemfuensis (ERX 7) and C. incompletus var. hirsutus (PI 29175301 PL 15) had the lowest DNA content and the greatest TLHL, because this measure is obtained from the average of the lengths of the homologous chromosomes, and does not take into account the number of chromosomes and ploidy of a species. Analyses of the karyotypes (Figure 2) revealed that these two accessions had larger chromosomes than the other accessions, as demonstrated by the TLHL. The TLHL can be influenced by the level of chromosome condensation, which explains a difference between the nuclear DNA content and the TLHL.

Genetics and Molecular Research 15 (4): gmr15049152 
Regarding chromosome morphology, there were only submetacentric chromosomes in the diploid C. incompletus var. hirsutus (PI 29175301 PL 15), which ranged from 1.7 to $6.2 \mu \mathrm{m}$ in length. There were only metacentric chromosomes in the other accessions/species. The only previous study using karyotypic data was conducted by Thomas and Murray (1978) for seven accessions of $C$. dactylon. The authors reported the occurrence of metacentric and submetacentric chromosomes, but those chromosomes had a total length of between 1 and $2 \mu \mathrm{m}$.

The parameters proposed by Stebbins (1971) pooled the accessions into three groups, and the parameters of Zarco (1986) and Peruzzi and Eroğlu (2013) grouped the accessions into two groups. The results obtained using the parameters of Stebbins (1971), Zarco (1986), and Peruzzi and Eroğlu (2013) to infer karyotype symmetry were similar, because both the scatter plot analysis and the classification of Stebbins (1971) showed that the karyotype of C. incompletus var. hirsutus (PI 29175301 PL 15) tended to be more asymmetric than the polyploids, which were a more homogeneous group. The karyotype of the diploid $C$. nlemfuensis (ERX 7) was the most symmetrical.

Symmetrical karyotypes mainly consist of metacentric and submetacentric chromosomes that are approximately the same size. Generally, species that are considered primitive in a group have symmetrical karyotypes with large numbers of chromosomes, whereas species with more asymmetric karyotypes are more derived. Asymmetry may increase due to the accumulation of differences in the relative sizes of chromosomes in the complement, making the karyotype more heterogeneous. Chromosomes can change their morphologies by rearrangements, such as pericentric inversions, uneven translocations, fissions, and centric fusions, which increase asymmetry. Therefore, karyotype variability can be used to identify evolutionary, chromosomal mechanisms in plants (Stebbins, 1958; Paszko, 2006; Techio et al., 2010).

The karyotype of the diploid accession C. incompletus var. hirsutus (PI 29175301 PL 15) consisted only of submetacentric chromosomes, and was the species with the most asymmetrical karyotype. Karyotype asymmetry increases as the centromere is gradually displaced from the middle to the end position (Zuo and Yuan, 2011). In C. nlemfuensis (ERX 7), which was also diploid but with a symmetrical karyotype, the chromosomes were metacentric and there was a gradual decrease in size, with little variation in chromosome length.

Our results demonstrate that Cynodon has variations in ploidy level but very similar karyotypes. Taxonomically, this variation in ploidy can generate numerous questions, as polyploids can be considered cytotypes with different ploidy levels or chromosomal races of the same species (Schifino-Wittmann, 2004). Chromosome counting, the construction and comparison of karyotypes, and the determination of ploidy level are very important tools in taxonomy. In this study, with the use of conventional cytogenetics, it was possible to identify a new chromosome number for C. transvaalensis, and reveal that accession PI 291755-24, identified as Cynodon sp, had a hybrid origin. However, the combination of karyotype and DNA content data was inadequate in accurately discriminating between all of the Cynodon accessions; for example, the accessions PI 224148-28 and PI 224147-13 were both identified as Cynodon sp and had the same chromosome number and morphology. There is, therefore, a need to investigate new cytogenetic markers in order to elucidate karyotype differences and separate accessions and species.

Regarding the accessions' relationships, the methodologies used for chromosome asymmetry showed that Cynodon sp (PI 291755-24) was closely linked to C. dactylon var. polevansii (PI 289750-10), while the other accessions that were identified as Cynodon sp (PI 224148-28 and PI 224147-13) were closer to each other. This observation can be extrapolated

Genetics and Molecular Research 15 (4): gmr15049152 
to C. dactylon var. dactylon (PI 291151-20) and C. transvaalensis (PI 289923-09), which had the same chromosome number, ploidy, DNA content, and karyotype formula. The diploid accessions C. incompletus var. hirsutus (PI 29175301 PL 15) and C. nlemfuensis (ERX 7), which had the same chromosome number, ploidy level, and DNA content, differed in karyotype formula and chromosomal asymmetry. C. nlemfuensis (ERX7) was close to the triploid Cynodon sp (PI 291755-24) and the pentaploid C. dactylon var. polevansii (PI 289750-10).

\section{Conflicts of interest}

The authors declare no conflict of interest.

\section{ACKNOWLEDGMENTS}

Research supported by Coordenação de Aperfeiçoamento de Pessoal de Nível Superior (CAPES), Conselho Nacional de Desenvolvimento Científico e Tecnológico (CNPq), and Fundação de Amparo à Pesquisa do Estado de Minas Gerais (FAPEMIG).

\section{REFERENCES}

Anderson WF, Maas A and Ozias-Akins P (2009). Genetic Variability of a Forage Bermudagrass Core Collection. Crop Sci. 49: 1347-1358. http://dx.doi.org/10.2135/cropsci2008.06.0330

Caro JA and Sánchez E (1969). Las especies de Cynodon (Gramineae) de la República Argentina. Kurtziana 5: 191-252.

Clayton WD, Vorontsova MS, Harman KT and Williamson H (2006). GrassBase- The online world grass flora. http:// www.kew.org/data/grasses-db.html. Accessed April 8, 2015.

de Lima JA and Vilela D (2005). Formação e manejo de pastagens de Cynodon. In: Cynodon: Forrageiras que estão revolucionando a pecuária Brasileira (Vilela D, Resende JC and de Lima J, eds.). Embrapa Gado de Leite, 11-32.

de Wet JMJ and Harlan JR (1970). Biosystematics of Cynodon L.C. Rich. (Gramineae). Taxon 19: 565-569. http://dx.doi. org $/ 10.2307 / 1218950$

de Wet JMJ and Harlan JR (1971). South African species of Cynodon (Gramineae). S. Afr. J. Bot. 37: 53-56.

Dhaliwal ARS and Gupta RC (2011). Cytological study on three cytotypes of Bermuda grass (Cynodon dactylon (L.) Pers.) from Haryana and Shiwalik hills. Int. J. Basic Appl. Biol. 5: 7-12.

Dolezel J (1997). Applications of flow cytometry for the study of plant genomes. J. Appl. Genet. 38: 285-302.

Dong F, Song J, Naess SK, Helgeson JP, et al. (2000). Development and applications of a set of chromosome-specific cytogenetic DNA markers in potato. Theor. Appl. Genet. 101: 1001-1007. http://dx.doi.org/10.1007/s001220051573

Ferreira DF (2011). Sisvar: a computer statistical analysis system. Cienc. Agron. 35: 1039-1042.

Forbes I and Burton GW (1963). Chromosome numbers and meiosis in some Cynodon species and hybrids. Crop Sci. 3: 75-79. http://dx.doi.org/10.2135/cropsci1963.0011183X000300010023x

Gulsen O, Sever-Mutlu S, Mutlu N, Tuna M, et al. (2009). Polyploidy creates higher diversity among Cynodon accessions as assessed by molecular markers. Theor. Appl. Genet. 118: 1309-1319. http://dx.doi.org/10.1007/s00122-009-0982-9

Gupta PK and Srivastava AK (1970). Natural triploidy in Cynodon dactylon (L.) Pers. Caryologia 23: 29-35. http://dx.doi. org $/ 10.1080 / 00087114.1970 .10796360$

Harlan JR, de Wet MJ and Richardson WL (1969). Hybridization studies with species of Cynodon from East Africa and Malagasy. Am. J. Bot. 56: 944-950. http://dx.doi.org/10.2307/2440636

Harlan JR, de Wet JMJ, Rawal KM, Felder MR, et al. (1970a). Cytogenetic studies in Cynodon L.C. Rich (Gramineae). Crop Sci. 10: 288-291. http://dx.doi.org/10.2135/cropsci1970.0011183X001000030023x

Harlan JR, de Wet JMJ and Huffine WW (1970b). A guide to the species of Cynodon (Gramineae). Bulletin B-673, Oklahoma Agricultural Experiment Station.

Jewell MC, Anderson WF, Loch DD, Godwin ID, et al. (2013). Introduction and adaptation of Cynodon L.C. Rich species in Australia. In: Breeding strategies for sustainable forage and turf grass improvement (Barth S and Milbourne D, eds.). Springer Sci. 231-237.

Kang SY, Lee GJ, Lim KB, Lee HJ, et al. (2008). Genetic diversity among Korean bermudagrass (Cynodon spp.) ecotypes characterized by morphological, cytological and molecular approaches. Mol. Cells 25: 163-171.

Genetics and Molecular Research 15 (4): gmr15049152 
Levan A, Fredga K and Souberg A (1964). Nomenclature for centromeric position on chromosomes. Hereditas 52: 201220. http://dx.doi.org/10.1111/j.1601-5223.1964.tb01953.x

Marie D and Brown SC (1993). A cytometric exercise in plant DNA histograms, with 2C values for 70 species. Biol. Cell 78: 41-51. http://dx.doi.org/10.1016/0248-4900(93)90113-S

Nani TF, Cenzi G, Pereira DL, Davide LC, et al. (2015). Ribosomal DNA in diploid and polyploid Setaria (Poaceae) species: number and distribution. Comp. Cytogenet. 9: 645-660.http://dx.doi.org/10.3897/CompCytogen.v9i4.5456

Nani TF, Perreira DL, Souza Sobrinho F and Techio VH (2016). Physical map of repetitive DNA sites in Brachiaria spp.: intravarietal and interspecific polymorphisms. Crop Sci. 56: 1769-1783. http://dx.doi.org/10.2135/ cropsci2015.12.0760

Nascimento MPSCB, Nascimento HTS and Leal JA (2002). Comportamento de cultivares de Cynodon no Piauí. Comunicado Técnico 146, Ministério da Agricultura, Pecuária e Abastecimento, Teresina.

Paszko A (2006). A critical review and a new proposal of karyotype asymmetry indices. Plant Syst. Evol. 258: 39-48. http://dx.doi.org/10.1007/s00606-005-0389-2

Pedreira CGS (1996). Avaliação de novas gramíneas de gênero Cynodon para a pecuária dos Estados Unidos. In: Workshop Sobre o potencial forrageiro do gênero Cynodon, Embrapa Gado de Leite, 111-125.

Peruzzi L and Eroğlu HE (2013). Karyotype asymmetry: again, how to measure and what to measure? Comp. Cytogenet. 7: 1-9. http://dx.doi.org/10.3897/compcytogen.v7i1.4431

Reeves A and Tear J (2000). MicroMeasure for Windows, version 3.3. http://www.colostate.edu/Depts/Biology/ MicroMeasure.

Schifino-Wittmann MT (2004). Poliploidia e seu impacto na origem e evolução das plantas silvestres e cultivadas. R. Bras. Agr. 10: 151-157.

Silva PHAU and Snaydon RW (1995). Chromosome number in Cynodon dactylon in relation to ecological conditions. Ann. Bot. (Lond.) 76: 535-537. http://dx.doi.org/10.1006/anbo.1995.1129

Stebbins GL (1958). Longevity, habitat. and release of genetic variability in the higher plants. Cold Spring Harb. Symp. Quant. Biol. 23: 365-378.http://dx.doi.org/10.1101/SQB.1958.023.01.035

Stebbins GL (1971). Chromosomal evolution in higher plants. Arnold, London.

Techio VH, Davide LC, Pereira AV and Bearzoti E (2002). Cytotaxonomy of some species and of interspecific hybrids of Pennisetum. Genet. Mol. Biol. 25: 203-209. http://dx.doi.org/10.1590/S1415-47572002000200014

Techio VH, Davide LC, Cagliari A, Barbosa S, et al. (2010). Karyotypic asymmetry of both wild and cultivated species of Pennisetum (Poaceae, Poales). Bragantia 69: 273-279. http://dx.doi.org/10.1590/S0006-87052010000200003

Thomas SM and Murray BG (1978). Herbicide tolerance and polyploidy in Cynodon dactylon (L.) Pers. (Gramineae). Ann. Bot. 42: 137-143.

Vaio M, Speranza P, Valls JF, Guerra M, et al. (2005). Localization of the $5 \mathrm{~S}$ and $45 \mathrm{~S}$ rDNA sites and cpDNA sequence analysis in species of the Quadrifaria group of Paspalum (Poaceae, Paniceae). Ann. Bot. (Lond.) 96: 191-200. http:// dx.doi.org/10.1093/aob/mci168

Vilela D (2005). Potencial das Pastagens de Cynodon na pecuária de leite. Cynodon: Forrageiras que estão revolucionando a pecuária brasileira (Vilela D, Resende JC and de Lima J, eds). Embrapa Gado de Leite, Juiz de Fora.

Wu Y (2011). Cynodon. In: Wild crop relatives: genomic and breeding resources millets and grasses (Kole C, ed.). Institute of Nutraceutical Research, USA, 344.

Wu Y and Taliaferro CM (2009). Bermuda grass. In: Genetic resources, chromosome engineering, and crop improvement (Forage crops vol. 5) (Singh RJ, ed.). CRC Press, New York, 289.

Wu YQ, Taliaferro CM, Bai GH, Martin DL, et al. (2006). Genetic analyses of Chinese Cynodon accessions by flow cytometry and AFLP markers. Crop Sci. 46: 917-926. http://dx.doi.org/10.2135/cropsci2005.08.0256

Zarco CR(1986). A new method for estimating karyotype asymmetry. Taxon 35:526-530. http://dx.doi.org/10.2307/1221906

Zhi-Yun G, Chao X, Ming-Liang Z and Miao W (2013). Distribution of rDNA loci and genome differentiation in tetraploid Cynodon. Indian J. Genet. Plant Breed. 73: 459-461. http://dx.doi.org/10.5958/j.0975-6906.73.4.071

Zuo L and Yuan Q (2011). The difference between the heterogeneity of the centromeric index and intrachromosomal asymmetry. p. Plant Syst. Evol. 297: 141-145. http://dx.doi.org/10.1007/s00606-011-0528-x

Genetics and Molecular Research 15 (4): gmr15049152 